\title{
Southern Libraries and Research
}

Library Resources and Graduate Work: The Development of Library Resources and Graduate Work in the Cooperative University Centers of the South: Proceedings of a Conference of Graduate Deans and Librarians Held at the Joint University Libraries, Nashville, Tennessee, July I214, 1944. Edited by Philip G. Davidson and A. F. Kuhlman. Nashville, Joint University Libraries, I944. viii, 8Ip.

All too frequently, in years past, college and university librarians have been accustomed to meet and discuss among themselves -without benefit of others in the hierarchy of learning - the problems, practices, and policies of modern librarianship in its relation to education. That such single-barreled conferences fell short of desired goals or ofttimes failed completely to modify established principles of educational procedures might conceivably be attributed to the absence of two most important catalyzing forces, the administrator and the teacher. Without them the librarian is in no better position to lift the level of learning than they are, let us say, without him. Indeed, it is difficult to imagine any one of the triumvirate accomplishing his objective without the supporting cooperation of his associates. In other words, the sooner librarians, school, college, or university, decide to invite their educational colleagues to serve with them in the solving of the perplexities of their profession, the more nearly successful they are likely to be.

The shoe also fits the other foot. Almost any librarian could offhand cite several instances in which courses were added to the college curriculum without his knowledge or advice. And there have been, amazingly enough, occasions within recent years when "complete" studies or surveys of educational institutions were undertaken without much or any consideration of library facilities. Only recently (1944) one Southern state, appointing a board of some fifteen or sixteen nationally-known consultants in various fields, undertook a "comprehensive" survey of all its institutions of higher learning. But there was no library consultant appointed. Not until a month or more had gone by and the omission had become embarrassingly obvious was a librarian invited to participate. In another instance a group of Southern college librarians were asked by their administrators to analyze their libraries in preparation for future coordinate expansion, but the feasibility of integrating curriculums as a prerequisite for wise purchasing was given no serious consideration.

Surely the time is now come for the triumvirate of higher education-the teacher, the librarian, and the administrator-to realize that their progress is mutually dependent one upon the other. Alone none can get far enough. Together, so long as there is understanding and a recognition of the fact that no one doubts the common goal, they can get far.

One evidence of cooperation among college and university administrators, instructors, and librarians was the week-long Conference on Higher Education sponsored by the Southern Association at Sewanee, Tenn., in June 1942. ${ }^{1}$ There representatives of almost every branch of the educational family met to try to work out the common problems of all. Significant decisions were reached. A common denominator of effort was firmly established. And as a valuable by-product came a mutual appreciation of the many-fingered tasks that confront all who strive to improve the higher educational status of the region. ${ }^{2}$

Another conference, and the one which prompts these remarks, was the Conference of Graduate Deans and Librarians, held at the Joint University Libraries, Nashville, Tenn., July 12-I4, 1944. Although primarily concerned with graduate resources in the four cooperative university centers of Georgia, Louisiana, North Carolina, and Tennessee ${ }^{3}$ those representing "the emergence of a new pattern in higher education and library development which is the product of cooperation

\footnotetext{
1 The Southern Association Quarterly 6:457-546, November 1942 .

2 Hoole, W. Stanley. "The Place of the College Library." Journal of Higher Education 14:370-73, October 1943 .

3 The "centers" include (I) Agnes Scott College Emory University, Georgia School of Technology, and the University of Georgia; (2) Louisiana State'University, Loyola University, Tulane University, and the New Orleans Public Library; (3) Duke University and the University of North Carolina; and (4) George Peabody College, Scarritt College, and Vanderbilt University.
} 
among institutions strategically located to render a significant regional service"-the agenda of this meeting were prepared jointly by librarians, teachers, and deans, and bore the endorsement of the Conference on Cooperative Opportunities in Higher Education of the Southern University Conference. Membership of the conference also included representatives from five individual university libraries in the Southeast (Alabama, Arkansas, Kentucky, South Carolina, and Tennessee) and, as consultants, five authorities possessing "extraordinary experience in fields of concern to the conference."

Working on the premise of the necessity of basic principles of coordination, the conference adopted as its purpose the exploration and definition of "the opportunities for the development of library resources for research and the improvement of advanced instruction and research in these university centers through cooperative effort."

Quite naturally, one approach to the many problems confronting the group was historical. Brief reviews of the establishment and meaning of the university centers led quickly to discussions of research work done in the South, the relative strength of supporting university libraries, the wasteful duplication of acquisitions and unwise competition, and, ultimately, the inadequate financial support of college and university libraries within the region. Here, it was frankly admitted, the South is "confronted with most baffling problems." In July 1943, for instance, Duke University Library (the largest in the Southeast) ranked sixteenth in size among university libraries in the United States. North Carolina, Joint University, and Virginia ranked thirty-third, thirty-fourth, and thirtysixth, respectively; and, excluding Duke, the fifteen largest university libraries in the Southeast combined had fewer volumes than Harvard University. Furthermore, only one (again, Duke) of twenty-seven American libraries holding more than a half million books is in the region.

Baffling though this situation may seem, there is evidence enough to explain it. In the words of North Carolina's J. Gordon Coogler:

Alas for the South; her books have grown fewer-

She never was much given to literature.
Doubtless the poet had in mind the writing of books, while here the discussion concerns the buying of books. During 1938/39-1940/4I the University of Chicago averaged expenditures of $\$ 75,890$ annually for books alone. In 1942-43 America's fifteen largest universities (none of which is in the Southeast) averaged $\$ 275$, IOI for books and services as compared to an average of only $\$ 90,700$ for nineteen Southern universities, including Duke's high of $\$ 218,109$ and Mississippi's low of $\$ 24,249$.

That such comparatively inadequate university libraries exist in the South is a wellknown fact. That their impoverishment is always to be balanced finally with the economic and social level of the region is another matter, one deserving careful consideration in any analysis. The South has been rightly described as America's economic problem child. With the lowest per capita income of the nation, the region strives conscientiously and not without some success to maintain dual public library systems, as well as dual educational systems, including, of course, dual college and university library systems. Briefly put, the South's nickel must go twice as far as the North's or West's dime. And that mathematical problem, a century old, is still incapable of solution.

If the South is to build and maintain adequate university libraries for advanced instruction and research, it must, as Library Resources and Graduate Work recommends, make use of every opportunity "for concerted library action," especially on the upper levels. This would include coordination of acquisitions, proper division of labor, logical disposition of gift collections, a study of deposit libraries, cooperation in document and newspaper programs, and a careful analysis of the problems presented by bibliographical centers, microphotography, joint purchasing, duplication, and interlibrary loans. It also includesand this is of utmost importance-a careful coordination of curriculums for advanced instruction and research "in order to avoid needless and wasteful duplication and competition and to assure better coverage, superior graduate instruction and research, and more competent special subject collections." Moreover, basic cooperation is dependent upon clearly drawn lines of curricular demarcations and generous financial support of li- 
braries. For these, as the book indicates, there is no substitute.

Library Resources and Graduate Work is without doubt one of the most important documents concerning librarianship to come out of the South in recent years. It has done much to focus attention on a problem so pressing and so gigantic as to be almost overwhelming-yet the way it was conjointly attacked by administrators, teachers, and librarians alike lends high hopes for the future.
For their significant contribution to higher education in the South, Philip G. Davidson, dean of the Graduate School of Vanderbilt University, and A. F. Kuhlman, director, Joint University Libraries, deserve the sincere thanks of educators throughout the nation. Their accomplishments, reflected as they are in Library Resources and Graduate Work, should do much toward charting a proper course for future Southern scholarship and research.-W. Stanley Hoole, director of libraries, University of Alabama.

\section{Wisconsin Manuscripts}

Guide to the Manuscripts of the Wisconsin Historical Society. Edited by Alice E. Smith. Madison, State Historical Society of Wisconsin, 1944. 290p.

This guide is the work of the curator of the Wisconsin Historical Society's manuscript division, assisted by the members of the staff of the Historical Records Survey of Wisconsin. In the preface the editor says the collection contains over 720,000 pieces and 2,500 volumes of manuscripts, a vast accumulation for any society. Certainly it is one of the largest and richest in the United States in the character of its materials. The guide makes no attempt to list individual items, and packages containing ten or fewer items are not listed. But, as it is, any student may obtain a clear idea whether there is any major amount of material for his researches at Madison.

No one conversant with the history of American manuscript collections will be surprised at the richness of the library's resources. The Wisconsin Historical Society, in its nearly one hundred years of history, had in the formative years two of the ablest collectors in the field to direct its workLyman C. Draper and Reuben Gold Thwaites. Either Draper's collection of nearly five hundred volumes of manuscripts relating to the first great West or Thwaites's on the French in the Northwest and on the records of his own state, would make any society famous. The John R. Commons collection on the history of labor and the papers of the economist, Richard T. Ely, also are of more than local significance.
The Wisconsin Historical Society has assumed as its primary task the gathering of material for the history of its own environment. But in common with the practice among other historical societies, the collection has become national in scope. Whatever source material will help the citizens of Wisconsin to better understand the nation's past has become grist for zealous assembling and arrangement for use. A study of the guide, with its record of correspondence, diaries, minutes of meetings, reminiscences, personal papers, addresses, and public documents, should serve similar agencies and individuals everywhere in knowing what to save.

There are more than eight hundred historical societies, large and small, some very small, in the United States. That means one for every 150,000 people. The ambition of the American people to secure for all time the materials for their own history has become a major industry. The Handbook of Historical Societies in the United States and Canada, published by the American Association for State and Local History, Washington, 1944, and the Wisconsin guide are manuals greatly needed by those who would be intelligent leaders in an important field of modern social activities.

The United States may not have the monuments of the Old World, but it can have, if it does not already have, the best basis for an understanding of its own past. There is a growing list of similar guides available for scholars. Most notable among the recent ones are Howard H. Peckham's Guide to the 